\title{
A VÁRANDÓSSÁG ALATTI DEPRESSZIÓ ÉS SZORONGÁS SZOCIO-DEMOGRÁFIAI RIZIKÓTÉNYEZÖI*
}

\section{Kopcsó Krisztina}

\section{ÖSSZEFOGLALÓ}

A várandósság idején fennáló depresszió és szorongás a várandósok körülbelül ötödét érintő, az anya és a gyermek egészségére is negatív hatást gyakorló mentális problémák, amelyek előfordulására a korábbi kutatások eredményei szerint befolyást gyakorolhatnak az anya szocio-demográfiai jellemzői. Jelen elemzés célja a várandósság alatti depresszió és szorongás szocio-demográfiai kockázati tényezőkkel mutatott összefüggéseinek feltárása a mai magyarországi várandósok populációjára nézve reprezentatív hazai mintán. Az elemzés tárgyát a Kohorsz '18 Magyar Születési Kohorszvizsgálat első szakaszának adatai adták ( $n=7701)$. A szorongás és depresszió felmérése önkitöltős szürőeszközökkel történt, amelyek alapján a harmadik trimeszterben járó várandósok 12,5\%-ánál volt valószínűsithető depresszió és 15,8\%-uk esetén szorongásos zavar. A várandósság alatti depresszió és szorongás fennállásának valószínűsége az egyváltozós statisztikai elemzésekben mindegyik vizsgált prediktor változóval (iskolai végzettség, életkor, paritás, partnerkapcsolati helyzet, várandósság tervezettsége, háztartás jövedelme, saját és partner munkaviszonya, lakhely) szignifikáns összefüggést mutatott. A többváltozós statisztikai elemzésben a prediktor változók hatása a várandós és a partnere munkaviszonyának kivételével változatlanul fennállt, és összességében a várandósság alatti depresszió és szorongás varianciájának 9-14\%-át magyarázta. Az elemzés eredményei igazolták, hogy az

* Jelen tanulmány elkészülte és a Kohorsz '18 kutatás adatfelvétele az EFOP-1.9.4-VEKOP-16-2016-00001 azonosítószámú, „A szociális ágazat módszertani és információs rendszereinek megújítása” című kiemelt projekt keretében valósult meg. 
alacsonyabb iskolai végzettség, a fiatalabb életkor, a többgyermekesség, a nem házas családi állapot, a nem tervezett várandósság, a háztartás alacsony jövedelme és az észak-magyarországi, észak-alföldi, valamint pesti lakhely összefüggést mutatnak a várandósság alatti szorongás és depresszió fennállásának magasabb kockázatával, ugyanakkor az egyének közötti különbségek csupán csekély részéért felelnek. A vizsgált rizikótényezők közül a depressziós és/vagy szorongásos tünetek fennállásának valószínűségéhez a többváltozós modellben az járult hozzá a legnagyobb mértékben, ha a várandósnak nem volt vele élő partnere, ha a harmadik vagy többedik gyermekét várta, ha a háztartásának a jövedelme az alsó ötödhöz tartozott, és ha a lakhelye Pest régióban volt.

Tárgyszavak: prenatális depresszió; prenatális szorongás; várandósság, rizikótényezők

Kopcsó Krisztina, Népességtudományi Kutatóintézet

E-mail:kopcso@demografia.hu 


\section{BEVEZETÉS}

A várandósság normatív krízisnek tekinthető, amely jelentős alkalmazkodást igényel, és esetenként pszichés tünetekhez vezethet. Az erre irányuló kutatások az általánosságban is legnagyobb prevalenciát mutató (World Health Organization, 2017) depresszív és szorongásos zavarokat a leggyakrabban előforduló prenatális pszichológiai problémákként tárgyalják (Bödecs et al., 2013). A várandósság alatti szorongás kapcsán egyfelől az ebben az időszakban jelen lévő, a szorongásos zavarok (pl. generalizált szorongásos zavar, pánikzavar, különféle fóbiák) közé sorolt tünetegyütteseket említhetjük meg, amelyekben a vezető tünet a túlzott mértékủ félelem, szorongás és aggodalom. Másfelől vizsgálhatjuk a személy általános, illetve a várandóssággal összefüggő szorongásszintjének mértékét, mintegy folytonos változóként. A depresszió klinikai kórképére a szomorúság/lehangoltság mellett csökkent érdeklődés és az örömérzésre való képtelenség, a testsúly-/étvágyváltozás, csökkent gondolkodási/összpontosítási/ döntési képesség, alacsony önértékelés, alvászavar, fáradtság/energiátlanság érzése, agitáció vagy éppen gátoltság, és a halál/öngyilkosság gondolatával való gyakori foglalkozás jellemző. A diagnózis felállitásához az említettek közül meghatározott számú tünetnek kell ugyancsak meghatározott ideig jelen lennie (American Psychiatric Association, 2013). A klinikai tünetegyüttes (egyszeri vagy visszatérő major depresszív zavar) meglétének megállapítása mellett azonban szintén létjogosultsága lehet a depressziv tünetsúlyosság vizsgálatának. A várandósság alatti szorongás és depresszió következményeit kutató elemzések gyakrabban vizsgálják a szorongásos és depresszív tünetek önbeszámolós tesztekkel felmért súlyosságát (akár folytonos, akár kategoriális változókként kezelve azt), mint a szakember által megállapított klinikai tünetegyüttes fennállását, amelynek hátterében főként a diagnosztikai interjúk alkalmazásának és finanszírozásának nehézsége állhat (Dunkel Schetter and Tanner, 2012).

Elméleti szempontból aközött is különbséget tehetnénk, hogy a szorongásos/depresszív zavar a várandósságot megelőzően és aközben egyaránt fennáll (vagyis a várandósság a pszichológiai probléma fennállása alatt következett be), a várandósság alatt lép fel azzal összefüggésben, vagy pedig a várandósság alatt lép fel, ám attól függetlenül. Gyakorlati szempontból ennek a vizsgálatára azonban csak kevés kutatási elrendezés alkalmas, így jelen adatok sem teszik ezt lehetővé. Mindemellett azt is fontos szem előtt tartani, hogy a várandósság során természetesen fellépő szomatikus tünetek - étvággyal, alvással kapcsolatos problémák, fáradtság - nehezítik a depresszív zavar felismerését, mert ha depresszív tüneteknek tekintjük őket, az a depresszív zavar felüldiagnosztizálásához, 
az ellenkezője pedig az aluldiagnosztizálásához vezethet. Ugyan ezek a testi tünetek a várandósság idején egyébként is gyakoriak, az étvágyváltozás kivételével azonban gyakrabban jelennek meg depresszív zavarral diagnosztizált nők esetén (Nylen, Williamson, O’Hara, Watson, and Engeldinger, 2013).

A nagyobb mértékű szorongással vagy depresszióval jellemezhető várandósok amellett, hogy több szomatikus panaszt tapasztalnak, több időt töltenek betegszabadságon, többször fordulnak orvoshoz, valamint gyakrabban választják az epidurális érzéstelenítést és a tervezett császármetszést is (Andersson, Sundström-Poromaa, Wulff, Åström, and Bixo, 2004). A prenatális depresszió összefüggést mutat a nem megfelelő súlygyarapodással, a magasabb mértékű alkoholfogyasztással, szerhasználattal és dohányzással (Zuckerman, Amaro, Bauchner, and Cabral, 1989). A várandósság alatti szorongás és depresszió az anya szülést követő szorongását és depresszióját is előre jelzik (Hompoth, Gálosi, Becsei, és Töreki, 2020; Hompoth, Töreki, Baloghné Fürész, és Németh, 2017; Lefkovics et al., 2018). A prenatális depresszió, szorongás és stressz feltehetőleg a fentiekkel is összefüggésben negatív hatást gyakorol a születendő gyermek fejlődésére (Bussières et al., 2015; Dunkel Schetter and Tanner, 2012; Grigoriadis et al., 2013; Hollins, 2007; Togher, Treacy, O’Keeffe, and Kenny, 2017), amelyek közül kiemelkedik a koraszülés és a kis születési súly kockázatának a növekedése. Ez a negatív hatás a felnövekedés későbbi időszakában is megmutatkozik, a várandósság idején tapasztalt anyai depresszió és szorongás mértéke ugyanis összefüggést mutat a gyermek későbbi szocio-emocionális (Madigan et al., 2018) és kognitív (Kingston, McDonald, Austin, and Tough, 2015; Tuovinen et al., 2018) fejlődésével.

Elemzésem célja a várandósság alatti depresszív és generalizált szorongásos tünetek szocio-demográfiai kockázati tényezőinek számbavétele, a Kohorsz '18 Magyar Születési Kohorszvizsgálat várandósság alatt felvett, önbeszámolón alapuló adatainak alapján. Amint az az alábbi szakirodalmi összefoglalóban körvonalazódik, külföldi elemzésekben számos társadalmi és demográfiai tényező bizonyult relevánsnak ezek vonatkozásában, melyek egy részének jelentősége magyarországi minták esetén is elemzésre került (Bödecs et al., 2013; Dudas et al., 2012; Hompoth et al., 2020, 2017; Lefkovics et al., 2018). 


\section{A VÁRANDÓSSÁG ALATTI DEPRESSZIÓ ÉS SZORONGÁS EPIDEMIOLÓGIÁJA}

Woody, Ferrari, Siskind, Whiteford és Harris (2017) 96 kutatást összegző metaanalízisének tanulságai szerint a prenatális depresszió előfordulási aránya alacsony és közepes bevételű országokban 19,2, míg a magas bevételekkel rendelkező országokban 9,2\% volt. Dennis, Falah-Hassani és Shiri (2017) 102 kutatást összegző metaanalízise pedig azt mutatta, hogy a várandósok 15,2\%-a küzd klinikailag diagnosztizálható szorongásos zavarral. Szorongásos tüneteket öszszességében ennél többen, a várandósok 22,9\%-a tapasztalt (az első trimeszterben 18,2, a másodikban 19,1, a harmadikban pedig 24,6\%). A prevalenciaértékek ez esetben is különböztek az ország bevétele szerint: alacsony és közepes jövedelmü országokban a szorongásos zavar (18,2\%) és a szorongásos tünetek $(34,4 \%)$ előfordulása egyaránt gyakoribb volt, mint a magas bevételű országok esetén (13,4\% és 19,4\%). A depresszív és szorongásos zavarok együttes fennállása meglehetősen gyakori (Rush et al., 2005), ami a várandósság alatti szorongás és depresszió vonatkozásában is megfigyelhető (Falah-Hassani, Shiri, and Dennis, 2017).

Nagyobb, hazai kutatásokból főként a prenatális depresszióról állnak rendelkezésre adatok, amelyek 8-tól 20\%-ig terjedő prevalenciáról adnak számot. Hompoth és munkatársai (2017) szegedi perinatális depressziószürésre ( $n=3849$ ) támaszkodó eredményei szerint a magyar várandósok 6,5-10,8\%-ánál valószínűsíthető minor vagy major depresszió, és a depressziós várandósok aránya az első trimeszterben a legmagasabb (10,8\%), majd a második (6,9\%) és harmadik (6,5\%) trimeszterben alacsonyabb. Hompoth és munkatársai (2020) békéscsabai depressziószűrésen $(n=1708)$ alapuló kutatása alapján a várandósok 11,9-15,3\%-ánál valószínűsithető minor vagy major depresszió, ami szintén a harmadik trimeszterben volt a legalacsonyabb (11,9\%). A depressziós várandósok arányának csökkenése szempontjából számottevő lehet a felmérések szürésen alapuló módszertana, ami ideális esetben intervenciót is von maga után. Dudas és munkatársai (2012) Délkelet-Magyarországon lezajlott kutatásának eredménye szerint (n=1719) a 12-24. hét között felmért várandósok 17,2\%-ánál valószínűsíthető depresszió. Végül Bödecs és munkatársainak (2013) Szombathely bizonyos védőnői körzeteire kiterjedt, teljes körű ( $n=503)$ kutatása - amely egyaránt vonatkozott a depresszióra és a szorongásra - arra az eredményre jutott, hogy várandósságuk első trimeszterében a gyermeket váró nők 14,2\%a vonásszorongás, 19,9\%-a pedig enyhe, közepes vagy súlyos depresszió jelét mutatta. 


\section{A VÁRANDÓSSÁG ALATTI DEPRESSZIÓ ÉS SZORONGÁS KOCKÁZATI TÉNYEZÖI}

A prenatális depresszió és szorongás kockázati tényezőinek kapcsán gazdag külföldi szakirodalmi háttér áll rendelkezésünkre, több áttekintő tanulmánnyal (Bayrampour, Vinturache, Hetherington, Lorenzetti, and Tough, 2018; Biaggi, Conroy, Pawlby, and Pariante, 2016; Lancaster et al., 2010). Biaggi és munkatársai (2016) 97 tanulmány (köztük 12 áttekintő tanulmány) összegzése révén vizsgálták a várandósság alatti depresszió és szorongás pszicho-szociális és környezeti rizikófaktorait. Elemzésükben a következő szocio-demográfiai rizikófaktorokat azonosították (figyelembe véve azon tanulmányok számát, amelyekben az adott tényező rizikófaktornak bizonyult, szemben azokéval, amelyekben nem): egyedülálló partnerkapcsolati státusz (14 vs. 5), nem tervezett vagy nem kívánt terhesség (22 vs. 2), alacsony iskolai végzettség (17 vs. 9), és alacsony jövedelem (15 vs. 3). Az eredmények a munkanélküliség (11 vs. 6) és a kisebbségi etnikum (7 vs. 4) esetén vegyesebbnek mutatkoztak. Az életkor kapcsán 13 kutatás a fiatal, míg 10 az idős életkort találta rizikófaktornak, további 10 kutatás nem mutatott ki összefüggést az életkor és a várandósság alatti szorongás vagy depresszió között. A paritást illető eredmények hasonlóképp vegyesnek mutatkoztak: 5 tanulmány a többgyermekes, 3 kutatás az első gyermekét váró anyák esetén mutatott ki nagyobb rizikót, 10 pedig nem mutatott ki összefüggést a paritás és várandósság alatti depresszió/szorongás között. Ezzel összhangban a graviditást vizsgáló kutatások is vegyes eredményeket mutattak: 2 szerint a már több alkalommal várandós, míg 1 szerint az első alkalommal várandós anyák depresszió-/szorongásszintje magasabb, 2 kutatás pedig nem talált összefüggést. Végül a partner munkanélkülisége jelentősnek bizonyult (4 vs. 0), de ennek megítélésére mindeddig csupán kevés adat áll rendelkezésre. A szocio-demográfiai tényezők mellett a kutatás természetesen a pszicho-szociális és egészségi rizikófaktorokra (pl. a partnerkapcsolat minősége, a partner támogatása, korábbi mentális betegség, negatív életesemények, abúzus, terhességi komplikációk, szerhasználat stb.) is kiterjedt, igazolva azok jelentőségét.

A hazai vizsgálatok a fenti összefüggésekkel többnyire összhangban állnak. Dombi, Berta és Jámbori (2019) hozzáférési mintán ( $n=364$ ) igazolták a depresszió nagyobb mértékét multiparitás és nem tervezett várandósság esetén. A szerzők elemzésében a depresszió előfordulása az anya iskolai végzettségével, lakóhelyével, családi állapotával és életkorával nem mutatott összefüggést, a vizsgálatban azonban jelentősen alulreprezentáltak voltak az alacsony iskolai végzettségű személyek. A jövedelem, illetve a várandós és a partnere munkavi- 
szonyának a hatását nem vizsgálták. Hompoth és munkatársai (2017) a várandósság alatti depresszió magasabb mértékét mutatták ki nem tervezett várandósság, 26 év alatti vagy 34 év fölötti életkor, egyedülálló családi állapot, illetve multiparitás esetén. Hompoth és munkatársai (2020) vizsgálatában az életkor és a családi állapot csak az első trimeszterben befolyásolta a depresszió előfordulását, amit ekkor a 21 év alattiak és az egyedülálló anyák nagyobb hányadánál valószínűsítettek. A nem tervezett várandósságok mindhárom trimeszterben a depresszió nagyobb előfordulásával jártak együtt, a multiparitás negatív hatása ebben a felmérésben azonban csak tendenciaerősséggel mutatkozott meg. Az iskolai végzettség, jövedelem, munkanélküliség, lakhely hatását Hompoth és munkatársai (2017, 2020) nem vizsgálták. Dudas és kollégái (2012) vizsgálata szintén alátámasztotta az egyedülálló családi állapot, az alacsony iskolai végzettség, a multiparitás, a nem tervezett várandósság, és a szubjektíven megítélt roszszabb anyagi háttér összefüggéseit a depresszióval, valamint a felmérésükben a tanyán élő várandósok körében magasabb volt a depresszió becsült előfordulása. A várandós vagy partnerének munkaviszonyának meglétét közvetlenül nem vizsgálták, azonban egyváltozós elemzésben a nem depressziós anyák nagyobb hányada tervezte, hogy a posztpartum időszakot követően visszamegy dolgozni, ami feltehetőleg összefüggött az anyák fennálló munkaviszonyával. Az életkor, a gyermekek száma, és az hogy valaki élettársi vagy házastársi kapcsolatban élt kutatásukban nem mutatott összefüggést a depresszióval, és többváltozós elemzésben a szocio-demográfiai változók közül már csak a multiparitás, valamint a nem tervezett várandósság bizonyult rizikófaktornak. Bödecs és munkatársai (2013) a várandósság alatti szorongást és depressziót egyaránt vizsgálva azt találták, hogy mindkét probléma előfordulása magasabb a munkanélküli, a 20 évesnél fiatalabb, az alacsony iskolai végzettségü, és a rosszabb anyagi helyzetű várandósoknál. A párkapcsolati státusz csak a depresszió esetén bizonyult relevánsnak: az élettársi kapcsolatban élők a házasságban élőkhöz viszonyítva több depresszív tünettel küzdöttek. A paritás, a várandósság tervezettsége, a lakhely, és a partner munkaviszonyának hatását nem vizsgálták.

Ami tehát a szocio-demográfiai változókat illeti, a külföldi szakirodalommal részben összhangban a hazai mintán megerősitést nyert a multiparitás, az alacsony iskolai végzettség, az egyedülálló partnerkapcsolati státusz, a nem tervezett várandósság, a rosszabb anyagi helyzet, továbbá a munkanélküliség mint rizikófaktorok - jelentősége. Az élettársi kapcsolatot, és az életkort illető eredmények nem mutattak egyértelmü képet, a partner munkanélküliségének, valamint az etnikumnak az esetleges hatásai nem kerültek felmérésre. A hazai prevalenciaadatok, így például a szegedi, békéscsabai, szombathelyi, és délke- 
let-magyarországi előfordulási arányok különbözőségei annak a lehetőségét is felvetik, hogy a prenatális depresszió és szorongás esetleg területi különbségeket is mutat, ám ezt eddig még egyetlen átfogó kutatás keretein belül nem vizsgálták.

Jelen elemzés célja a szóban forgó potenciális rizikófaktorok várandósság alatti depresszióval és szorongással mutatott összefüggéseinek feltárása reprezentatív hazai mintán, különös hangsúllyal a korábban felmérésre nem került vagy vegyes eredményeket mutató változókra. Az etnikai kisebbséghez tartozás esetleges hatását mindazonáltal az elemzés nem vizsgálja, mert annak felmérésére a Kohorsz '18 kutatás első hullámában nem került sor.

\section{MÓDSZER}

\section{Minta és eljárás}

Az elemzés a KSH Népességtudományi Kutatóintézet (NKI) által folytatott Kohorsz '18 Magyar Születési Kohorszvizsgálat első, várandós szakaszának adatain történt ( $n=8287$ ). A Kohorsz '18 kutatás súlyozott, várandós adatbázisa a 2018-ban várandós anyák populációjára nézve reprezentatív (iskolai végzettséget, paritást, hivatalos családi állapotot, életkort, illetve a lakhely fejlettségi mutatóját tekintve), és azon anyák közel 10\%-át foglalja magában, akik a várandósgondozási könyvben rögzített adatok alapján a 2018 április 1 . és 2019 április 30. közötti időszakra várták a gyermekük születését (lásd bővebben Kapitány, 2018; Szabó et al., 2020). Az adatbázis a várandósok lakhelyének földrajzi elhelyezkedését illetően nem tekinthető reprezentatívnak.

A mintavétel a védőnői körzeteken alapuló, és a területek társadalmi státuszát is figyelembe vevő véletlen kezdőpontú szisztematikus mintavétellel történt. A mintába kerülő védőnői körzetekben az adott időszakra gyermeket váró nők kutatásra való felkérése teljes körü volt. A várandós nők felkérését és lekérdezését az NKI által képzett védőnők végezték a várandósok tájékoztatását és írásos beleegyezését követően. Az adatfelvétel ajánlott ideje a várandósság 28-31. hete közé esett, a várandósok lekérdezése azonban az esetek 3\%-ában ennél korábban, 11\%-ában pedig ennél később történt. A kutatás módszertanáról további részletes információkat tartalmaz a témában megjelent két jelentés (Szabó et al., 2020; Veroszta, 2018).

Az elemzés a várandós adatgyűjtés két forrására, a védőnők által szóban lekérdezett főkérdőív súlyozott adataira, és a gyermeket váró nők által kitöltött 
önkitöltős kérdőív ehhez kapcsolt adataira támaszkodott. Jelen elemzésbe azon várandósok adatait vontuk be, akik lekérdezése a harmadik trimeszterben történt (a 28. terhességi héten vagy azt követően), és akiknek teljes körü adatai álltak rendelkezésre a vizsgált kimeneti változók vonatkozásában $(n=7701)$.

\section{Változók}

Az elemzés kimeneti változói a várandósság alatti depresszió és generalizált szorongásos zavar fennállásának valószínüsége, amelyek meghatározása önkitöltős szűrőskálák segitségével történt. A szorongásos tüneteket a Generalized Anxiety Disorder-2-skála (GAD-2; Kroenke, Spitzer, Williams, Monahan, and Löwe, 2007) magyar fordítása (http://www.phqscreeners.com) révén mértük fel. A GAD-2skála két tételt tartalmaz, amelyek esetén a várandósok négyfokú Likert-skálán jelezték, hogy az elmúlt két hétben milyen gyakran tapasztaltak bizonyos érzéseket, viselkedésmódokat ( $0=$ =gyszer sem, $3=$ majdnem mindennap). A pontszáma így 0 és 6 pont között változhat.

A depresszív tüneteket pedig a Center for Epidemiologic Studies-Depressionkérdőív (Radloff, 1977) 8 tételes változatával (CESD-D-8; Bracke, Levecque, and Van de Velde, 2008) mértük fel, amelynek magyar fordítását Szeifert (2010) adaptációjából ültettük át. A CESD-D-8-skála összesen 8 tételt tartalmaz, ameIyeknél a várandósok szintén négyfokú Likert-skálán jelezték, hogy az elmúlt egy hétben milyen gyakran tapasztaltak bizonyos érzéseket vagy viselkedéseket ( $0=$ =ritkán vagy soha [1 napnál rövidebb ideig], 3=legtöbbször vagy állandóan [5-7 napig]). A pontszám így 0 és 24 között változhat. A CES-D-8-skála hiányzó adatait legalább 80\%-os kitöltöttség esetén a személy által megválaszolt tételek átlagpontszámával helyettesítettük (lásd bővebben Szabó et al., 2020). Egyéb adathiányt tartalmazó esetek az elemzésből kihagyásra kerültek.

Mindkét kérdőív adatai jobbra ferde eloszlást mutattak. A kimeneti változók kategoriálissá alakítása mellett azok eloszlásait, az interpretálhatóságot, és a korábbi szakirodalmak módszertanát (Underwood, Waldie, D’Souza, Peterson, and Morton, 2017; Waldie et al., 2015) figyelembe véve döntöttem?. Mivel sem

\footnotetext{
1 Ugyan statisztikai szempontból egyéb megoldások is felmerülhetnének, véleményem szerint az elemzés eredményei dichotóm változókat alkalmazva interpretálhatóak igazán. A ferde eloszlás mind a depresszív, mind a szorongásos tünetek kapcsán magától értetődő, miszerint a válaszadók többsége csupán ritkán tapasztal ilyen jellegü tüneteket, míg néhányan igencsak gyakran. Jelen vizsgálat célja az utóbbi csoporthoz tartozás rizikótényezőinek elemzése, és nem tárgya a normatív tartományon belüli különbségek hátterének a vizsgálata.
} 
a CES-D-8-, sem a GAD-2-skálának nincs magyarra validált vágópontja, ennek meghatározásakor a külföldi vágópontokra, valamint a külföldi és a magyarországi prevalenciaadatokra támaszkodtam. A GAD-2-skála javasolt vágópontja z3 (Kroenke et al., 2007; NICE, 2014). Ezzel a vágóponttal jelen minta 15,8\%-ánál azonosítottuk a szorongásos zavar valószínüségét, amely érték összhangban van a korábbi szakirodalmi adatokkal (Bödecs et al., 2013; Dennis et al., 2017). A CES-D-8-skálának nincsen konszenzuális vágópontja. Mivel 7, 8, illetve 9 pontos vágópontot alkalmazva jelen várandós minta 23,4, 17,1 és 12,5\%-át azonosítanánk, a legújabb hazai és a magas bevételü országokra jellemző prevalenciaadatokat figyelembe véve jelen elemzésben a szigorúbbnak tekinthető $\geq 9$ vágópont mellett döntöttem.

A mentális betegségek korábbi és aktuális fennállását emellett a főkérdőív arra vonatkozó kérdései is felmérték, hogy a válaszadónak a várandósságot megelőzően és az adatfelvételkor volt-e orvos által megállapított depressziója vagy bipoláris hangulatzavara, illetve szorongásos zavara, kényszerbetegsége, pánikbetegsége vagy fóbiája, és amennyiben igen, úgy szed-e ezek valamelyikére gyógyszert. Az orvos által megállapított zavarok alacsony előfordulása végett (lásd Eredmények) ezek elemzésére azonban függő változóként nem került sor.

Prediktor változóként a következők kerültek bevonásra: (1) legmagasabb befejezett iskolai végzettség (alacsony, közepes, magas); (2) életkor (26 év alatti, 26-34 éves, 34 év fölötti); (3) paritás (első, második, harmadik, vagy negyedik vagy többedik gyermekét várja a várandós); (4) valós partnerkapcsolati helyzet (házastársával él, élettársával él, nincs együtt élő partnere); (5) nem tervezett várandósság (tervezett, nem tervezett ${ }^{3}$, bizonytalan vagy nem besorolható ${ }^{4}$ ); (6) jövedelem (a háztartás havi, nettó, ekvivalens jövedelme, ötödökbe sorolva); (7) munkaviszony megléte; (8) a partner munkaviszonyának megléte; (9) lakhely tervezési-statisztikai régiók szerinti felosztásban.

\footnotetext{
${ }^{2}$ Alacsony iskolai végzettségnek a legfeljebb szakmunkásképző vagy szakképzés érettségi nélküli végzettséget tekintettem. Közepes iskolai végzettségnek az ennél magasabb, de legfeljebb érettségit követő, felsőfokra nem akkreditált szakképzést vagy középfokú technikumi végzettséget tekintettem.

${ }^{3}$ A nem tervezett várandósságok a nem kivánt várandósságokat és a kivántnál előbb bekövetkezỏ várandósságokat egyaránt magukba foglalják.

${ }^{4}$ Ide tartozott, ha a várandós arra a kérdésre, szerette volna-e, hogy valaha még gyermeke szülessen, „,bizonytalan volt”, „,nem gondolkodott rajta” ",nem tudja” választ adott, vagy megtagadta a kérdésre a válaszadást, valamint, ha az időzitést illetỏ kérdésre „nem tudja” választ adott, vagy megtagadta a válaszadást.
} 


\section{Elemzés}

Az adatelemzést IBM SPSS Statistics 22 programban végeztem. Első lépésben egyváltozós statisztikai módszerrel, khínégyzet-próbákat alkalmazva vizsgáltam meg, hogy a depresszió és a szorongás előfordulása egyenként együtt jár-e az elemzésbe bevont prediktor változókkal. Ezek során az elsőfajú hibát csökkentendő, Bonferroni-korrekciót alkalmazva a szükséges szignifikanciaszintet p<,006-ban határoztam meg. Ezt követően logisztikus regressziós modellt alkalmaztam annak elemzésére, hogy az egyes prediktor változók többváltozós modellben miként növelik meg a depresszív és/vagy szorongásos tünetek fennállásának valószínúségét a tünetmentes csoporthoz viszonyítva, a változókat egyszerre bevonó (enter-) módszerrel. A tárgyalt többváltozós modell a partner munkaviszonyát nem tartalmazza, ugyanakkor két alternatív modell eredményeit is megvizsgáltam: ezek egyike a partner munkaviszonyának meglétét tartalmazta (de a partnerkapcsolati helyzetet nem), a másik pedig a mentális betegségek korábbi fennállását.

\section{EREDMÉNYEK}

\section{A kimeneti és prediktor változók jellemzői}

A GAD-2-skála pontszáma 0-6 között váltakozott, átlaga 1,45 ( $\mathrm{SD}=1,38)$ volt. A CES-D-8-skála pontszáma 0-24 között váltakozott, átlaga 4,63 (SD=3,58) volt. A skálák fentebb ismertetett vágópontjait alkalmazva a szorongásos zavar feltételezett előfordulása 15,8, a depresszió feltételezett előfordulása pedig 12,5\% volt. A komorbiditás lehetőségét vizsgálva azt az eredményt kapjuk, hogy feltehetőleg az elemzésbe bevont várandósok 21,3\%-a küzdött érzelmi-hangulati problémákkal: 5,5\% depresszióval, 8,8\% szorongással, 7\% komorbid (együttesen fennálló) depresszióval és szorongással. Ezek az előfordulások mindazonáltal a rizikótényezők elemzése miatt kerültek bevezetésre, epidemiológiai szempontból nem tekinthetőek megbízhatónak.

A prediktor változók részletes eloszlásait az 1. táblázat ismerteti. A várandósok átlagéletkora 29,59 év volt (SD=6,03). 
1. táblázat: A szocio-demográfiai változók eloszlásai

\begin{tabular}{|c|c|}
\hline Változó & $n(\%)$ \\
\hline $\begin{array}{l}\text { Iskolai végzettség ( } \mathrm{n}=7699) \\
\text { alacsony } \\
\text { közepes } \\
\text { magas }\end{array}$ & $\begin{array}{l}2354(30,6) \\
2627(34,1) \\
2718(35,3)\end{array}$ \\
\hline $\begin{array}{l}\text { Életkor }(n=7701) \\
\quad<25 \\
26-34 \\
>35\end{array}$ & $\begin{array}{l}1937(25,2) \\
4056(52,7) \\
1708(22,2)\end{array}$ \\
\hline $\begin{array}{l}\text { Paritás (n=7701) } \\
\text { első gyermekét várja } \\
\text { 2. gyermekét várja } \\
\text { 3. gyermekét várja } \\
\text { 4+ gyermekét várja }\end{array}$ & $\begin{array}{l}3644(47,3) \\
2529(32,8) \\
1029(13,4) \\
498(6,5)\end{array}$ \\
\hline $\begin{array}{l}\text { Partnerkapcsolati helyzet (n=7701 } \\
\text { házas } \\
\text { élettársi kapcsolatban él } \\
\text { nincs együtt élő partnere }\end{array}$ & $\begin{array}{l}4232(55) \\
3161(41) \\
308(4)\end{array}$ \\
\hline $\begin{array}{l}\text { Várandósság tervezettsége ( } \mathrm{n}=77 \\
\text { tervezett } \\
\text { nem tervezett } \\
\text { bizonytalan, nem besorolható }\end{array}$ & $\begin{array}{l}5112(66,4) \\
2008(26,1) \\
581(7,5)\end{array}$ \\
\hline $\begin{array}{l}\text { Jövedelmi ötödök (n=7014) } \\
\text { alsó ötöd } \\
\text { 2. ötöd } \\
\text { középső ötöd } \\
\text { 4. ötöd } \\
\text { felső ötöd }\end{array}$ & $\begin{array}{l}1381(19,7) \\
1377(19,6) \\
1351(19,3) \\
1496(21,3) \\
1409(20,1)\end{array}$ \\
\hline $\begin{array}{l}\text { Munkaviszony (n=7701) } \\
\text { nincs } \\
\text { van }\end{array}$ & $\begin{array}{l}2109(27,4) \\
5592(72,6)\end{array}$ \\
\hline $\begin{array}{l}\text { Partner munkaviszonya }(\mathrm{n}=7537) \\
\text { nincs } \\
\text { van }\end{array}$ & $\begin{array}{l}259(3,4) \\
7278(96,6)\end{array}$ \\
\hline $\begin{array}{l}\text { Lakhely (n=7701) } \\
\text { Észak-Magyarország } \\
\text { Észak-Alföld } \\
\text { Dél-Alföld } \\
\text { Budapest } \\
\text { Pest régió } \\
\text { Közép-Dunántúl } \\
\text { Dél-Dunántúl } \\
\text { Nyugat-Dunántúl }\end{array}$ & $\begin{array}{l}454(5,9) \\
1475(19,2) \\
823(10,7) \\
1309(17) \\
1055(13,7) \\
903(11,7) \\
1144(14,9) \\
537(7)\end{array}$ \\
\hline
\end{tabular}


Az orvos által megállapított mentális zavarokat illetően 69 fő (0,9\%) számolt be a várandósságot megelőzően fennálló, huszonketten (0,3\%) a várandósságot megelőzően és az alatt is meglévő, öten $(0,1 \%)$ pedig a várandósság alatt fennálló hangulatzavarról. A szorongásos zavar várandósság előtti előfordulását 102 fő (1,3\%), várandósság előtti és az alatti előfordulását nyolcvanan (1\%), kizárólag várandósság alatti előfordulását heten (0,1\%) jelezték. Hatan $(0,1 \%)$ szedtek gyógyszert hangulatzavarra, míg szorongásos zavarra 29 fő (0,4\%). Mivel a várandósság alatti orvos által megállapított hangulatzavar (0,35\%) és szorongásos zavar (1,13\%) gyakorisága egyaránt jelentősen elmaradt a korábbi prevalenciaadatok mentén feltételezhető értékektől, így ezen változók érvényességét kérdésesnek itéltem és a vizsgálatot nem terjesztettem ki rájuk.

A jelen elemzésbe való bevonás feltétele volt a harmadik trimeszterben történő adatfelvétel és a kimeneti változók megléte. A szorongás- és/vagy depresszióérték hiánya az esetek 4,2\%-ában állt fenn. Ennek a hiánynak az aránya összefüggést mutatott a várandós társadalmi-demográfiai helyzetével: nagyobb arányú adathiány állt fenn 26 év alatti és 34 év feletti életkor, több korábbi gyermek, nem házas családi állapot, nem tervezett várandósság, alacsony vagy nem ismert jövedelem, alacsony iskolai végzettség, munkanélküli várandósok, és munkanélküli partner esetén. Figyelembe véve a várandósság alatti mentális betegségek ismert rizikótényezőit feltételezhető tehát, hogy az elemzésből kieső résztvevők valamelyest növelték volna a depressziós és/vagy szorongásos tünetekkel jellemezhetők arányát.

Harmadik trimeszter előtti kérdezés az esetek 3\%-ában történt, ami szintén összefüggött néhány társadalmi-demográfiai változóval. A 28. hetet megelőző kérdezés valamelyest gyakoribb volt a 26 év feletti várandósok, a tervezett várandósság és a munkaviszonnyal rendelkező várandósok esetén. A harmadik trimeszter előtti kérdezés ténye a szorongás- és depreszszió értékeknek sem a meglétével, sem az értékével nem mutatott összefüggést. 


\section{A várandósság alatti depresszió és szorongás kockázati tényezőinek egyváltozós elemzése}

A várandósság alatti depresszió és szorongás fennállásának valószínűségét az egyváltozós statisztikai elemzésekben mindegyik vizsgált szocio-demográfiai változó (iskolai végzettség, életkor, paritás, partnerkapcsolati helyzet, várandósság tervezettsége, háztartás ekvivalens jövedelme, saját és partner munkaviszonyának léte, lakhely) szignifikánsan befolyásolta (lásd 2. és 3. táblázat).

A várandósság alatt fennálló depresszió aránya - a teljes mintán átlagosan $12,5 \%$ volt - különösen magas volt: az alacsony iskolai végzettség (22,3\%), a 25 év alatti életkor (18,5\%), a harmadik (17,5\%), a negyedik vagy többedik (24,4\%) gyermekét váró anya, a partner nélkül élő anya (33,4\%), a nem tervezett várandósság (20,1\%), vagy az ezt illető bizonytalanság, illetve válaszmegtagadás (20,1\%), az alsó jövedelmi ötödhöz tartozás (24\%), a saját (21,9\%) vagy a partner (21,6\%) munkaviszonyának hiánya, és az észak-alföldi lakhely (17,4\%) esetén.

A szorongás fennállását - a teljes mintán átlagosan $15,8 \%$ volt a gyakorisága szintén jelentősen növelte az alacsony iskolai végzettség (26\%), a 25 év alatti életkor (23,3\%), ha az anya harmadik (21,5\%), negyedik vagy többedik gyermekét várta (30,1\%), ha az anyának nem volt vele együtt élő partnere (30,5\%), a várandósság nem tervezettsége (25,4\%), vagy ehhez kapcsolódó bizonytalanság vagy válaszmegtagadás (23,2\%), az alsó jövedelmi ötödhöz tartozás (27,5\%), a saját (26,5\%) vagy a partner (25,9\%) munkaviszonyának a hiánya, és az északalföldi lakhely (22,8\%). 
2. táblázat. Depresszió előfordulásåa az egyes szocio-demográfiai csoportokban

\begin{tabular}{|c|c|c|c|}
\hline Változó & $\begin{array}{c}\text { Nem depressziós } \\
n(\%)\end{array}$ & $\begin{array}{c}\text { Depressziós } \\
\mathrm{n}(\%)\end{array}$ & Pearson $X^{2}$ \\
\hline $\begin{array}{l}\text { Iskolai végzettség (n=7698) } \\
\text { alacsony } \\
\text { közepes } \\
\text { magas }\end{array}$ & $\begin{array}{l}1830(77,7) \\
2361(89,9) \\
2547(93,7)\end{array}$ & $\begin{array}{l}524(22,3) \\
266(10,1) \\
170(6,3)\end{array}$ & $316,01^{* *}$ \\
\hline $\begin{array}{l}\text { Életkor }(n=7700) \\
\quad<25 \\
26-34 \\
>35\end{array}$ & $\begin{array}{l}1579(81,5) \\
3622(89,3) \\
1538(90)\end{array}$ & $\begin{array}{l}358(18,5) \\
433(10,7) \\
170(10)\end{array}$ & $85,92^{* *}$ \\
\hline $\begin{array}{l}\text { Paritás (n=7701) } \\
\text { első gyermekét várja } \\
\text { 2. gyermekét várja } \\
\text { 3. gyermekét várja } \\
\text { 4+ gyermekét várja }\end{array}$ & $\begin{array}{l}3297(90,5) \\
2217(87,7) \\
849(82,5) \\
377(75,6)\end{array}$ & $\begin{array}{l}348(9,5) \\
311(12,3) \\
180(17,5) \\
122(24,4)\end{array}$ & $117,90^{* *}$ \\
\hline $\begin{array}{l}\text { Partnerkapcsolati helyzet (n=7700) } \\
\text { házas } \\
\text { élettársi kapcsolatban él } \\
\text { nincs együtt élő partnere }\end{array}$ & $\begin{array}{l}3860(91,2) \\
2675(84,7) \\
205(66,6)\end{array}$ & $\begin{array}{l}372(8,8) \\
485(15,3) \\
103(33,4)\end{array}$ & $200,62^{* *}$ \\
\hline $\begin{array}{l}\text { Várandósság tervezettsége (n=7701) } \\
\text { tervezett } \\
\text { nem tervezett } \\
\text { bizonytalan, nem besorolható }\end{array}$ & $\begin{array}{l}4672(91,4) \\
1604(79,9) \\
464(79,9)\end{array}$ & $\begin{array}{l}440(8,8) \\
404(20,1) \\
117(20,1)\end{array}$ & $208,70^{* *}$ \\
\hline $\begin{array}{l}\text { Jövedelmi ötödök (n=7015) } \\
\text { alsó ötöd } \\
\text { 2. ötöd } \\
\text { középső ötöd } \\
\text { 4. ötöd } \\
\text { felső ötöd }\end{array}$ & $\begin{array}{l}1049(76) \\
1162(84,4) \\
1213(89,8) \\
1382(92,3) \\
1331(94,5)\end{array}$ & $\begin{array}{l}332(24) \\
215(15,6) \\
138(10,2) \\
115(7,7) \\
78(5,5)\end{array}$ & $280,76^{* *}$ \\
\hline $\begin{array}{l}\text { Munkaviszony }(n=7701) \\
\text { nincs } \\
\text { van }\end{array}$ & $\begin{array}{l}1648(78,1) \\
5092(91,1)\end{array}$ & $\begin{array}{l}461(21,9) \\
500(8,9)\end{array}$ & $233,97^{* *}$ \\
\hline $\begin{array}{l}\text { Partner munkaviszonya ( } \mathrm{n}=7537) \\
\text { nincs } \\
\text { van }\end{array}$ & $\begin{array}{l}203(78,4) \\
6431(88,4)\end{array}$ & $\begin{array}{l}56(21,6) \\
847(11,6)\end{array}$ & $23,64^{* *}$ \\
\hline $\begin{array}{l}\text { Lakhely (n=7701) } \\
\text { Észak-Magyarország } \\
\text { Észak-Alföld } \\
\text { Dél-Alföld } \\
\text { Budapest } \\
\text { Pest régió } \\
\text { Közép-Dunántúl } \\
\text { Dél-Dunántúl } \\
\text { Nyugat-Dunántúl }\end{array}$ & $\begin{array}{l}383(84,4) \\
1219(82,6) \\
733(89,1) \\
1197(91,4) \\
915(86,7) \\
814(90) \\
989(86,5) \\
489(91,1)\end{array}$ & $\begin{array}{l}71(15,6) \\
256(17,4) \\
90(10,9) \\
112(8,6) \\
140(13,3) \\
90(10) \\
154(13,5) \\
48(8,9)\end{array}$ & $69,58^{* *}$ \\
\hline
\end{tabular}

a A depresszió fennállása a 9 vagy annál nagyobb CES-D-8-pontszám alapján valószínűsített. **p<,001 
3. táblázat. Szorongás előfordulásaa az egyes szocio-demográfiai csoportokban

\begin{tabular}{|c|c|c|c|}
\hline Változó & $\begin{array}{c}\text { Nem szorongó } \\
n(\%)\end{array}$ & $\begin{array}{l}\text { Szorongó } \\
n(\%)\end{array}$ & Pearson $X^{2}$ \\
\hline $\begin{array}{l}\text { Iskolai végzettség ( } \mathrm{n}=7698) \\
\text { alacsony } \\
\text { közepes } \\
\text { magas }\end{array}$ & $\begin{array}{l}1743(74) \\
2259(86) \\
2480(91,3)\end{array}$ & $\begin{array}{l}611(26) \\
369(14) \\
237(8,7)\end{array}$ & $290,80^{* *}$ \\
\hline $\begin{array}{l}\text { Életkor }(n=7700) \\
\quad<25 \\
26-34 \\
>35\end{array}$ & $\begin{array}{l}1485(76,7) \\
3488(86) \\
1509(88,3)\end{array}$ & $\begin{array}{l}452(23,3) \\
567(14) \\
199(11,7)\end{array}$ & $114,72^{* *}$ \\
\hline $\begin{array}{l}\text { Paritás (n=7700) } \\
\text { első gyermekét várja } \\
\text { 2. gyermekét várja } \\
\text { 3. gyermekét várja } \\
\text { 4+ gyermekét várja }\end{array}$ & $\begin{array}{l}3201(87,8) \\
2124(84) \\
809(78,5) \\
348(69,9)\end{array}$ & $\begin{array}{l}443(12,2) \\
404(16) \\
221(21,5) \\
150(30,1)\end{array}$ & $137,82^{* *}$ \\
\hline $\begin{array}{l}\text { Partnerkapcsolati helyzet (n=7700) } \\
\text { házas } \\
\text { élettársi kapcsolatban él } \\
\text { nincs együtt élő partnere }\end{array}$ & $\begin{array}{l}3710(87,7) \\
2559(81) \\
214(69,5)\end{array}$ & $\begin{array}{l}522(12,3) \\
602(19) \\
94(30,5)\end{array}$ & $113,28^{* *}$ \\
\hline $\begin{array}{l}\text { Várandósság tervezettsége (n=7700) } \\
\text { tervezett } \\
\text { nem tervezett } \\
\text { bizonytalan, nem besorolható }\end{array}$ & $\begin{array}{l}4538(88,8) \\
1498(74,6) \\
446(76,8)\end{array}$ & $\begin{array}{l}573(11,2) \\
510(25,4) \\
135(23,2)\end{array}$ & $243,88^{* *}$ \\
\hline $\begin{array}{l}\text { Jövedelmi ötödök (n=7015) } \\
\text { alsó ötöd } \\
\text { 2. ötöd } \\
\text { középső ötöd } \\
\text { 4. ötöd } \\
\text { felső ötöd }\end{array}$ & $\begin{array}{l}1001(72,7) \\
1125(81,7) \\
1162(86) \\
1334(89,1) \\
1291(91,6)\end{array}$ & $\begin{array}{l}380(27,5) \\
252(18,3) \\
189(14) \\
163(10,9) \\
118(8,4)\end{array}$ & $238,91^{* *}$ \\
\hline $\begin{array}{l}\text { Munkaviszony }(n=7700) \\
\text { nincs } \\
\text { van }\end{array}$ & $\begin{array}{l}1550(73,5) \\
4932(88,2)\end{array}$ & $\begin{array}{l}558(26,5) \\
660(11,8)\end{array}$ & $247,35^{* *}$ \\
\hline $\begin{array}{l}\text { Partner munkaviszonya ( } \mathrm{n}=7537 \text { ) } \\
\text { nincs } \\
\text { van }\end{array}$ & $\begin{array}{l}192(74,1) \\
6177(84,9)\end{array}$ & $\begin{array}{l}67(25,9) \\
1101(15,1)\end{array}$ & $22,03^{* *}$ \\
\hline $\begin{array}{l}\text { Lakhely (n=7699) } \\
\text { Észak-Magyarország } \\
\text { Észak-Alföld } \\
\text { Dél-Alföld } \\
\text { Budapest } \\
\text { Pest régió } \\
\text { Közép-Dunántúl } \\
\text { Dél-Dunántúl } \\
\text { Nyugat-Dunántúl }\end{array}$ & $\begin{array}{l}366(80,8) \\
1139(77,2) \\
705(85,7) \\
1167(89,2) \\
881(83,5) \\
767(84,8) \\
975(85,3) \\
482(89,8)\end{array}$ & $\begin{array}{l}87(19,2) \\
336(22,8) \\
118(14,3) \\
142(10,8) \\
174(16,5) \\
137(15,2) \\
168(14,7) \\
55(10,2)\end{array}$ & $97,55^{* *}$ \\
\hline
\end{tabular}

a A szorongásos zavar fennállása a 3 vagy annál nagyobb GAD-2-pontszám alapján valószínűsített. **p<,001 


\section{A várandósság alatti depresszió és szorongás kockázati tényezőinek többváltozós elemzése}

Mivel a szorongás és a depresszió valószínüségét a rizikófaktorok azonos irányba látszottak befolyásolni, és az esetek 7\%-ában a depresszió és a szorongás egyébként is együttesen álltak fenn, a továbbiakban többváltozós modell segítségével azt a kérdést vizsgáltam, hogy a várandósság alatti depressziv és/ vagy szorongásos tünetek fennállásának valószínüségét mely tényezők milyen mértékben növelik meg a tünetmentes csoporthoz viszonyítva. ${ }^{5}$

Referenciakategóriának az egyváltozós statisztikai elemzések alapján legkisebb kockázatú csoportnak bizonyuló kategóriákat alkalmaztam. Ez a lakhely kivételével a depresszió és szorongás esetén egybeesett: lakhely vonatkozásában a Nyugat-Dunántúlt választottam referenciának, ahol a szorongás előfordulása 0,6 százalékponttal alacsonyabb, a depresszió előfordulása pedig 0,3\% százalékponttal magasabb volt, mint Budapesten.

Mivel a többváltozós modellbe nem volt érdemes beépíteni a partnerkapcsolati helyzetet és a partner munkaviszonyát is, ráadásul a partnerkapcsolati helyzet mind elméleti alapon, mind az egyváltozós statisztikai elemzések alapján meghatározóbb rizikófaktora a mentális betegségeknek, emiatt az itt részletesen ismertetett többváltozós modellben a partner munkaviszonya változó nem szerepel. ${ }^{6}$

A logisztikus regressziós modell ( $\mathrm{n=7052)}$ szignifikánsnak bizonyult $\left(-2 L L=6591,61 ; \chi_{(23)}^{2}=652,98\right.$ p<,001). Multikollinearitás nem állt fenn (VIF<2 minden esetben). A vizsgált társadalmi-demográfiai változók a várandósság alatti depresszió és szorongás varianciájának 9-14\%-át magyarázták ( $R^{2}=0,09$ (Cox and Snell), 0,14 (Nagelkerke)). A modellben összességében egyedül a gyermeket váró nő munkaviszonya nem bírt szignifikáns bejósló erővel. A modell értékeit részletesen a 4. táblázat ismerteti.

A jelentős mértékű várandósság alatti depresszió és/vagy szorongás fennállásának valószínüségét logisztikus regressziós modellben szignifikánsan növelte az alacsony $(O R=1,60)$ és a közepes $(O R=1,21)$ iskolai végzettség, a 26 év alatti $(O R=1,33)$ és a 26-34 éves (OR=1,20) életkor, ha az anya második (OR=1,43),

\footnotetext{
${ }^{5}$ A depressziv, a szorongásos és az együttesen fennálló tünetek rizikófaktorainak egyenként történő vizsgálata túlmutat jelen tanulmány keretein. A kétféle tünetegyüttes kockázati tényezőinek összevont vizsgálata mindazonáltal nem idegen a téma korábbi tárgyalásától (lásd például Biaggi et al., 2016), emellett a rizikófaktorok hasonlóságait hazai viszonylatban jelen tanulmány mellett Bödecs és munkatársai (2013) eredményei is igazolták.

${ }^{6} \mathrm{Az}$ alternatív modell (n=6929), amely a partner munkaviszonyát tartalmazza, a partnerkapcsolati helyzetet pedig nem, úgyszintén szignifikánsnak bizonyult (-2LL=6422,53; Model $\chi^{2}(22)=579,59, p<, 001, R^{2}=0,08$ [Cox and Snell], 0,13 [Nagelkerke]), ugyanakkor a partner munkaviszonyának hiánya nem bírt benne szignifikáns magyarázó erővel ( $p=, 682)$.
} 
harmadik $(\mathrm{OR}=1,86)$ vagy többedik $(\mathrm{OR}=1,89)$ gyermekét várta, ha élettársi kapcsolatban élt $(O R=1,19)$, vagy nem volt vele együtt élö partnere $(O R=2,19)$, ha a várandósság nem volt tervezett $(\mathrm{OR}=1,65)$, vagy az anya efelől bizonytalan volt vagy nem adott választ (OR=1,53), ha az anya háztartásának ekvivalens jövedelme az alsó (OR=1,88), a második (1,51), vagy a középső (OR=1,35) ötödbe esett, és ha az anya lakhelye Észak-Magyarországon ( $\mathrm{OR}=1,48)$, Észak-Alföldön $(\mathrm{OR}=1,56)$, vagy Pest régióban $(\mathrm{OR}=1,77)$ volt.

Tekintve, hogy várandósságot megelőzően esetlegesen fennálló mentális zavarok a mentális problémák aktuális előfordulása mellett a vizsgált szociodemográfiai tényezők egy részét (pl. iskolai végzettség, családi állapot, várandósság tervezettsége, jövedelem, munkaviszony) is nagymértékben érinthetik, a fenti modellt ezeket bevonva is ellenőriztem, és nagyobbrészt érvényesnek találtam. ${ }^{7}$

\footnotetext{
${ }^{7}$ A várandósságot megelőzően orvos által diagnosztizált depressziv és szorongásos zavarok elöfordulásának bevonása amellett, hogy értelemszerüen növelte a modell magyarázóerejét $\left(-2 L L=6514,71\right.$; Model $\chi^{2}(25)=729,88, p<, 001, R^{2}=0,10$ [Cox and Snell], 0,15 [Nagelkerke]), annyiban módosította annak eredményeit, hogy a közepes iskolai végzettség hatását „semlegesítette”, amely ebben a módosított modellben már nem bizonyult szignifikánsnak ( $p=, 051,0 R=1,19)$.
} 
4. táblázat. A depresszió és/vagy szorongás fennállásáta bejósló tényezők többváltozós modellje, tünetmentes csoporthoz viszonyitva

\begin{tabular}{|c|c|c|c|c|c|c|c|}
\hline Változó & $B$ & S.E. & OR & \multicolumn{2}{|c|}{$95 \% \mathrm{Cl}$} & $p$ & Wald \\
\hline $\begin{array}{l}\text { Iskolai végzettség } \\
\text { alacsony } \\
\text { közepes } \\
\text { magas (ref) }\end{array}$ & $\begin{array}{l}\text {,47 } \\
\text {,19 }\end{array}$ & $\begin{array}{l}11 \\
\text {,09, }\end{array}$ & $\begin{array}{l}1,60 \\
1,21\end{array}$ & $\begin{array}{l}1,29 \\
1,02\end{array}$ & $\begin{array}{l}1,98 \\
1,45\end{array}$ & $\begin{array}{l}, 000 \\
, 029 \\
, 000\end{array}$ & $\begin{array}{l}18,56^{* *} \\
4,76^{*} \\
19,056^{* *}\end{array}$ \\
\hline $\begin{array}{l}\text { Életkor } \\
\qquad 25 \\
26-34 \\
>35 \text { (ref) }\end{array}$ & $\begin{array}{l}\text {,29 } \\
\text {,19 }\end{array}$ & $\begin{array}{l}\text {,11 } \\
\text {,09 }\end{array}$ & $\begin{array}{l}1,33 \\
1,20\end{array}$ & $\begin{array}{l}1,08 \\
1,02\end{array}$ & $\begin{array}{l}1,66 \\
1,42\end{array}$ & $\begin{array}{l}, 009 \\
, 030 \\
, 027\end{array}$ & $\begin{array}{l}6,86^{*} \\
4,69^{*} \\
7,22^{*}\end{array}$ \\
\hline $\begin{array}{l}\text { Paritás } \\
\text { első gyermekét várja (ref) } \\
\text { 2. gyermekét várja } \\
\text { 3. gyermekét várja } \\
\text { 4+ gyermekét várja }\end{array}$ & $\begin{array}{l}, 36 \\
, 62 \\
, 64\end{array}$ & $\begin{array}{l}, 08 \\
, 10 \\
13\end{array}$ & $\begin{array}{l}1,43 \\
1,86 \\
1,89\end{array}$ & $\begin{array}{l}1,23 \\
1,53 \\
1,46\end{array}$ & $\begin{array}{l}1,66 \\
2,25 \\
2,44\end{array}$ & $\begin{array}{l}, 000 \\
, 000 \\
, 000 \\
, 000\end{array}$ & $\begin{array}{l}48,57^{* *} \\
22,37^{* *} \\
39,26^{* *} \\
23,96^{* *}\end{array}$ \\
\hline $\begin{array}{l}\text { Partnerkapcsolati helyzet } \\
\text { házas (ref) } \\
\text { élettársi kapcsolatban él } \\
\text { nincs együtt élő partnere }\end{array}$ & $\begin{array}{l}17 \\
\text {,79 }\end{array}$ & $\begin{array}{l}\text {,07 } \\
\text {,15 }\end{array}$ & $\begin{array}{l}1,19 \\
2,19\end{array}$ & $\begin{array}{l}1,04 \\
1,64\end{array}$ & $\begin{array}{l}1,37 \\
2,93\end{array}$ & $\begin{array}{l}, 000 \\
, 014 \\
, 000\end{array}$ & $\begin{array}{l}29,03^{* *} \\
6,08^{*} \\
28,57^{* *}\end{array}$ \\
\hline $\begin{array}{l}\text { Várandósság tervezettsége } \\
\text { tervezett } \\
\text { nem tervezett } \\
\text { bizonytalan, nem besorolható }\end{array}$ & $\begin{array}{l}, 50 \\
, 42\end{array}$ & $\begin{array}{l}\text {,07 } \\
\text {,11 }\end{array}$ & $\begin{array}{l}1,65 \\
1,53\end{array}$ & $\begin{array}{l}1,43 \\
1,23\end{array}$ & $\begin{array}{l}1,91 \\
1,90\end{array}$ & $\begin{array}{l}, 000 \\
, 000 \\
, 000\end{array}$ & $\begin{array}{l}49,24^{* *} \\
46,65^{* *} \\
14,26^{* *}\end{array}$ \\
\hline $\begin{array}{l}\text { Jövedelmi ötödök } \\
\text { alsó ötöd } \\
\text { 2. ötöd } \\
\text { középső ötöd } \\
\text { 4. ötöd } \\
\text { felső ötöd (ref) }\end{array}$ & $\begin{array}{l}, 63 \\
, 41 \\
, 30 \\
, 21\end{array}$ & $\begin{array}{l}, 13 \\
, 12 \\
, 12 \\
, 12\end{array}$ & $\begin{array}{l}1,88 \\
1,51 \\
1,35 \\
1,23\end{array}$ & $\begin{array}{l}1,47 \\
1,19 \\
1,07 \\
0,98\end{array}$ & $\begin{array}{l}2,42 \\
1,91 \\
1,70 \\
1,55\end{array}$ & $\begin{array}{l}, 000 \\
, 001 \\
, 011 \\
, 070 \\
, 000\end{array}$ & $\begin{array}{l}24,53^{* *} \\
11,66^{*} \\
6,46^{*} \\
3,27 \\
26,65^{* *}\end{array}$ \\
\hline $\begin{array}{l}\text { Munkaviszony } \\
\text { nincs } \\
\text { van (ref) }\end{array}$ & ,13 & ,08 & 1,14 & 0,97 & 1,34 & 117 & 2,46 \\
\hline $\begin{array}{l}\text { Lakhely } \\
\text { Észak-Magyarország } \\
\text { Észak-Alföld } \\
\text { Dél-Alföld } \\
\text { Budapest } \\
\text { Pest régió } \\
\text { Közép-Dunántúl } \\
\text { Dél-Dunántúl } \\
\text { Nyugat-Dunántúl (ref) }\end{array}$ & $\begin{array}{l}, 39 \\
, 45 \\
, 12 \\
, 24 \\
, 57 \\
, 24 \\
, 14\end{array}$ & $\begin{array}{l}, 18 \\
, 15 \\
16 \\
, 16 \\
, 15 \\
16 \\
, 15\end{array}$ & $\begin{array}{l}1,48 \\
1,56 \\
1,13 \\
1,28 \\
1,77 \\
1,27 \\
1,15\end{array}$ & $\begin{array}{l}1,05 \\
1,17 \\
0,83 \\
0,94 \\
1,31 \\
0,93 \\
0,85\end{array}$ & $\begin{array}{l}2,10 \\
2,08 \\
1,55 \\
1,73 \\
2,39 \\
1,73 \\
1,55\end{array}$ & $\begin{array}{l}, 027 \\
, 002 \\
, 441 \\
, 120 \\
, 000 \\
, 137 \\
, 373 \\
, 000\end{array}$ & $\begin{array}{l}4,91^{*} \\
9,32^{*} \\
0,59 \\
2,41 \\
13,78^{* *} \\
2,22 \\
0,79 \\
30,79^{* *}\end{array}$ \\
\hline
\end{tabular}

a Depresszió fennállása valószínűsithető a 9 vagy annál nagyobb CES-D-8-pontszám alapján, és/vagy szorongásos zavar fennállása valószínűsíthető a 3 vagy annál nagyobb GAD-2-pontszám alapján. ***<<,001 * $p<, 05$ 


\section{MEGVITATÁS}

Jelen elemzés a várandósság harmadik trimesztere idején fennálló generalizált szorongásos és depresszív zavar valószínűségét növelő társadalmi-demográfiai rizikótényezők vizsgálatát tủzte ki célul. Az alkalmazott szűrőeszközök révén a várandósok 21,3\%-ánál azonosítottuk a mentális problémák valószínűségét: a szorongásos tünetek feltételezett előfordulása 15,8, a depresszív tüneteké 12,5\% volt, és az esetek 7\%-ában a két probléma együttesen állt fenn.

Az elemzés eredményei igazolták a várandósság alatti szorongás és depresszió szocio-demográfiai tényezőkkel mutatott összefüggéseit. Egyváltozós elemzésekben az összes vizsgált prediktor változó (iskolai végzettség, életkor, paritás, partnerkapcsolati helyzet, várandósság tervezettsége, háztartás jövedelme, saját és partner munkaviszonyának léte, lakhely) összefüggést mutatott a várandósság alatti szorongással és depresszióval. A depresszió és a szorongás előfordulása egyaránt abban az esetben volt a legmagasabb, ha az anyának nem volt vele együtt élő partnere, ha negyedik vagy többedik gyermekét várta, és ha háztartásának jövedelme az alsó ötödhöz tartozott. Lakhely vonatkozásában mindkét probléma előfordulása Budapesten és a Nyugat-Dunántúlon volt a legalacsonyabb. A zavarok feltételezhető előfordulása egyaránt az észak-alföldi és az észak-magyarországi lakhely esetén volt a legnagyobb, emellett valamelyest magasabb előfordulást figyeltünk meg a Pest régióban levő lakhely esetén. Mindemellett a szorongásos zavar feltételezhető előfordulása a dél-dunántúli várandósok körében is kismértékben átlagon felüli volt.

Többváltozós elemzésben együttesen megvizsgálva a szorongás és depresszió rizikótényezőit szintén azt az eredményt kaptuk, hogy ezek fennállásának valószínüségét legnagyobb mértékben - a házasokhoz viszonyítva 2,2-szeresére - az fokozta, ha az anyának nem volt vele együtt élő partnere, tehát egyedülálló volt vagy látogató partnerkapcsolatban élt. Ez megfelel azon korábbi eredményeknek, melyek szerint az egyedülálló kapcsolati állapot kockázati tényezőnek tekinthető (Biaggi et al., 2016; Dudas et al., 2012; Hompoth el al., 2017; Hompoth et al., 2020). Az élettársi kapcsolat Bödecs és munkatársai (2013) eredményei szerint csak a depresszió esetén rizikófaktor, szorongás esetén nem. Jelen kutatásban a két zavar előfordulásának valószínűségét az élettársi kapcsolat a házastársi kapcsolathoz képest szignifikánsan növelte, ugyanakkor csupán 1,2-szeresére.

Kutatásunkban szintén közel kétszeresére növelte a magas depresszió és/ vagy szorongás előfordulásának valószínüségét, ha az anya a harmadik vagy többedik gyermekét várta (az első gyermekét váróhoz viszonyítva), ha háztartásának jövedelme az alsó ötödhöz tartozott (a felső ötödhöz viszonyítva), és 
ha Pest régióban élt (Nyugat-Dunántúlhoz viszonyítva). A második gyermek várása (az első gyermekét váróhoz viszonyítva), valamint a második és a középső jövedelmi ötödhöz tartozás (a felső ötödhöz viszonyítva) szintén szignifikánsan, ám kisebb mértékben fokozták a mentális problémák valószínüségét. Jelen eredmények konzisztensek a korábbi multiparitást (Dombi et al., 2019; Dudas et al., 2012; Hompoth et al., 2017), és szubjektív anyagi helyzetet (Bödecs et al., 2013, Dudas et al., 2012) vizsgáló hazai eredményekkel. Ugyan a paritást illető külföldi vizsgálatok vegyesebb képet mutatnak (Biaggi et al., 2016), és hazánkban is előfordult olyan vizsgálat, amely nem támasztotta alá a többgyermekesség negatív hatását (Hompoth et al., 2020), jelen elemzés eredményei alapján a többedik, különösen a legalább harmadik gyermek várása egyértelmű rizikótényező, függetlenül az anya további szocio-demográfiai jellemzőitől. Figyelemre méltó, hogy míg Dudas és munkatársai (2012) a szubjektíven megítélt rossz anyagi helyzet (ennek előfordulása kutatásukban 19,3\% volt a vélhetően depressziós és 11,2\% a vélhetően nem depressziós várandósok esetén) hatását csak egyváltozós elemzésben mutatták ki, többváltozós elemzésben már nem, addig jelen kutatás többváltozós elemzéseinek eredményei szerint minél kisebb a háztartás jövedelme, annál fokozottabb a várandósság alatti szorongás és depresszió valószínűsége. A magas depresszió- és/vagy szorongásszintet leginkább valószínűsitő egyedüláló vagy látogató partnerkapcsolati státusz, az alacsony jövedelem és a sokgyermekesség közös vonása lehet a gyermekvárást és a gyermek felnevelését övező bizonytalanság, vagy épp az, hogy az anya sokféle teendővel és nehézséggel néz szembe a mindennapokban, amelyek miatt nem tudja teljes figyelmét a várandósságnak szentelni.

A regionális adatokat illetően Nyugat-Dunántúlhoz viszonyítva a Pest régióban található, valamint az észak-magyarországi és észak-alföldi lakhely bizonyult szignifikáns rizikótényezőnek. Az elemzés tehát alátámasztja azon - legjobb tudomásom szerint elsőként tesztelt - feltevést, hogy a várandósság idején fellépő szorongás és depresszió területi különbségeket mutat, és ezek szempontjából, kontrollálva az összes további vizsgált szocio-demográfiai változó hatását Pest régió, Észak-Alföld és Észak-Magyarország a legveszélyeztetettebb. Korábbi magyarországi felmérések alapján (Bödecs et al., 2013; Dudas et al, 2012; Hompoth et al., 2017, 2020) a prenatális depresszió előfordulása a harmadik trimeszterben a dél-alföldi Szegeden és Békéscsabán az Edinburgh Postnatal Depression Scale kérdőívvel mérve 6,5 és 11,9\%, Délkelet-Magyarországon (amely egyszersmind tartalmaz dél-alföldi és észak-alföldi megyéket) a Leverton Questionnaire kérdőívvel mérve a 14-24. héten 17,2\%, a Nyugat-Dunántúlon fekvő SzombatheIyen kilenctételes Beck Depression Inventory kérdőívvel mérve az első trimesz- 
terben 19,9\% volt. Jelen kutatás eredményei - miszerint a depresszió feltételezett előfordulása Dél-Alföldön 10,9, Észak-Alföldön 17,4, Nyugat-Dunántúlon pedig 8,9\% - arra utalnak, hogy a korábban közölt dél-alföldi és délkelet-magyarországi prevalenciaadatok különbségei valós területi eltéréseket jelezhetnek (ami főként a magasabb észak-alföldi előfordulásból fakad), a korábban kapott, kiemelkedően magas szombathelyi prevalenciaarány azonban vélhetően inkább módszertani sajátosság (pl. a használt depresszióskálának vagy a trimeszterek között megfigyelhető különbségeknek) következménye. Megjegyzendő azonban, hogy jelen kutatás földrajzi szempontból nem volt reprezentatív, és Szombathely nem tartozott a mintához, így az sem zárható ki, hogy Szombathelyen magasabb az előfordulás, mint más, a kutatásban részt vevő nyugat-dunántúli városokban. A jövőbeni kutatásoknak érdemes lehet tovább vizsgálnia a regionális eltéréseket, és hogy a körvonalazódó különbségek hátterében milyen területspecifikus tényezők húzódhatnak meg.

A nem tervezett, vagy későbbre tervezett várandósság a korábbi szakirodalomnak megfelelően növelte a depresszív és/vagy szorongásos tünetek előfordulását (Biaggi et al.; Dombi et al., 2019; Dudas et al., 2012; Hompoth et al., 2017; Hompoth et al., 2020), és érdekes módon a bizonytalan válaszadók vagy a válaszmegtagadók körében a kockázat közel ugyanakkora volt a tervezett várandóssághoz viszonyítva, mint a nem vagy a későbbre tervezett gyermekeket váró anyák körében. Jelen kutatásban a nem vagy a későbbre tervezett várandósság aránya 26,1, a bizonytalan vagy a nem besorolható válaszadók aránya pedig további 7,5\% volt, vagyis összesen a várandósok 33,6\%-áról nem jelenthető ki bizonyosan, hogy (ekkorra) tervezték a teherbe esésüket. Ez lényegesen magasabb arány, mint amelyet Hompoth és munkatársai (2017, 2020) a szürésen alapuló kutatásaikban nem tervezett várandósságként megállapítottak (11,1, illetve 9,52\%), és felhívja a figyelmet arra, hogy a várandósság alatti pszichológiai problémák rizikójának felmérésekor a várandósság tervezettségét és időzítését érdemes lehet több kérdéssel felmérni, megengedve a bizonytalan választ és a válasz megtagadását is, tudva, hogy ezek is utalhatnak a várandósság alatti szorongás és depresszió fokozott valószínüségére.

Az iskolai végzettség jelentősége a várandósság alatti depresszió és szorongás vonatkozásában konzisztens bizonyos korábbi eredményekkel (Biaggi et al., 2016; Bödecs et al., 2013; Dudas et al., 2012). Ugyan Bödecs és kollégái (2013) csak a legalacsonyabb iskolai végzettséget azonosították kockázati tényezőként, jelen elemzés eredményei arra utalnak, hogy mind az alacsony, mind a közepes iskolai végzettség rizikótényezőnek tekinthető, ugyanakkor az alacsony iskolai végzettség hatása sokkal számottevőbb. 
Az életkor Biaggi és munkatársai (2016) átfogó vizsgálatában vegyes eredményeket hozott, és a korábbi hazai eredmények sem voltak konzisztensek: a 26 év alatti és 34 év feletti korcsoport magasabb depressziószintje (Hompoth et al., 2017), a 20 év alattiak magasabb szorongás- és depressziószintje (Bödecs et al., 2013), valamint a 21 év alattiak magasabb depresszió szintje (Hompoth et al., 2020) egyaránt kimutatásra került, akárcsak a korral mutatott összefüggés hiánya (Dombi et al., 2019). Jelen eredmények arra engednek következtetni, hogy a várandósság alatti érzelmi-hangulati problémák előfordulása a 34 év feletti korosztályban a legalacsonyabb, hozzájuk viszonyítva pedig mind a 26-34 éves, mind a 26 év alatti anyák körében valamelyest gyakoribb.

A jelen elemzésben vizsgált prediktor változók közül az EMMI hatályos szakmai irányelve (2017) az egyedülálló partnerkapcsolati státuszt, a nem tervezett várandósságot és az anya munkanélküliségét sorolja fel a perinatális depresszió rizikófaktorai között, és a gyermekágyi lehangoltság előfordulásával összefüggő tényezőként említi még az iskolázottságot, a családi háttért és az életkort is (a 35 év feletti életkort jelölve meg a legkockázatosabb időszaknak). Mindemellett, a depresszióval is összefüggő perinatális öngyillkosság rizikófaktorai között szerepelteti a fiatal életkort, a nem házas családi állapotot, az etnikai kisebbséghez tartozást, a túlzsúfolt/nem megfelelő, illetve vidéki lakhelyet és a nulliparitást. Amellett, hogy jelen elemzés eredményei megerősítik az egyedülálló családi állapothoz tartozó magasabb kockázatot, rávilágítanak arra is, hogy a multiparitás - különösen ha az anya a harmadik vagy többedik gyermekét várja - és a háztartás alacsony jövedelme közel olyan mértékben fokozza a depresszió és a szorongás valószínűségét, mint amikor az anyának nincs együtt élő partnere, de kiemelendő még az alacsony iskolai végzettség jelentősége is. Figyelemre méltóak a várandósság alatti mentális problémákat illető területi különbségek is. Mindemellett az eredmények arra is rámutatnak, hogy manapság 35 év felett nem tekinthetök különösen veszélyeztetettnek a várandósok a mentális problémák szempontjából, ami összefügghet a gyermekvállalás egyre későbbre tolódásával (Kapitány és Spéder, 2018), aminek köszönhetően kezd megszokottá válni, hogy a nők 35 éves koruk felett vállalnak gyermeket.

Az, hogy a várandósnak vagy partnerének volt-e aktuálisan munkaviszonya az adatfelvétel idején, a többváltozós modellben vizsgálva nem növelte a várandósság alatti depresszió vagy szorongás előfordulásának kockázatát. Ez a korábbiakban esetenként kimutatott (Biaggi et al., 2016; Bödecs et al., 2013) egyváltozós összefüggés tehát vélhetően a többi vizsgált társadalmi-demográfiai változóval magyarázható. 
Jelen kutatás legmeghatározóbb korlátja a mentális problémák azonositási módja, amely rövid szürőeszközök felvételéből állt, ezek eredményeként a tünetsúlyosságról kaphattunk csak képet, míg a klinikai diagnózisok (specifikus szorongásos és hangulati tünetekből álló tünetegyüttesek) előfordulási gyakoriságáról nem. A jövőben fontos volna a felmért szocio-demográfiai kockázati tényezők jelentőségének vizsgálata a klinikailag diagnosztizálható szorongásos és depresszív problémák szempontjából is. Szintén fontos lenne a használt mérőeszközök vágópontjainak klinikai validálása. Emellett a mérés egyszeri alkalommal valósult meg, méghozzá a harmadik trimeszterben, így nem tudhatjuk, hogy a depressziv/szorongásos tünetek előfordulása átmeneti, vagy tartós volt-e, és eredményeink nem általánosithatóak a várandósság egész időtartamára. Végül nem áll rendelkezésünkre a válaszadók által igénybe vett gyógyszeres és pszichoterápiás kezelésekre vonatkozó teljes körü információ, amelyek azonban valamelyest „elfedhetik” a kockázati tényezők kedvezőtlen hatásait. Mindazonáltal a kutatás limitációival is összefüggő erőssége, hogy reprezentatív hazai mintán elemezte a várandósság alatti depresszió és szorongás szocio-demográfiai kockázati tényezőit, a nagy mintaelemszám által lehetővé váló többváltozós statisztikai módszertannal.

Összességében a kutatás eredményei arra hívják fel a figyelmet, hogy a várandósok pszichológiai jólléte nem független a társadalmi és demográfiai hátterüktől, és a sérülékenyebb csoportok esetén a depresszió és szorongás rutinszerủ szűrésének fokozott jelentőségét igazolják. A jövőbeni kutatásokban érdemes volna kiterjeszteni a vizsgálat fókuszát a várandósok etnikai kisebbséghez tartozására. 


\section{IRODALOM}

American Psychiatric Association (2013). Diagnostic and Statistical Manual of Mental Disorders, fifth edition. Washington, DC: American Psychiatric Publishing.

Andersson, L., Sundström-Poromaa, I., Wulff, M., Åström, M., and Bixo, M. (2004). Implications of Antenatal Depression and Anxiety for Obstetric Outcome. Obstetrics \& Gynecology, 104(3), 467-476. https://doi.org/10.1097/01.AOG.0000135277.04565.e9

Bayrampour, H., Vinturache, A., Hetherington, E., Lorenzetti, D. L., and Tough, S. (2018). Risk factors for antenatal anxiety: A systematic review of the literature. Journal of Reproductive and Infant Psychology, 36(5), 476-503. https://doi.org/10.1080/02646 838.2018.1492097

Biaggi, A., Conroy, S., Pawlby, S., and Pariante, C. M. (2016). Identifying the women at risk of antenatal anxiety and depression: A systematic review. Journal of Affective Disorders, 191, 62-77. https://doi.org/10.1016/j.jad.2015.11.014

Bödecs, T., Szilágyi, E., Cholnoky, P., Sándor, J., Gonda, X., Rihmer, Z., and Horváth, B. (2013). Prevalence and psychosocial background of anxiety and depression emerging during the first trimester of pregnancy: Data from a Hungarian population-based sample. Psychiatria Danubina, 25(4), 352-358.

Bracke, P., Levecque, K., and Van de Velde, S. (2008). The psychometric properties of the CES-D 8 depression inventory and the estimation of cross-national differences in the true prevalence of depression. Ghent: Ghent University.

Bussières, E.-L., Tarabulsy, G. M., Pearson, J., Tessier, R., Forest, J.-C., and Giguère, Y. (2015). Maternal prenatal stress and infant birth weight and gestational age: A meta-analysis of prospective studies. Developmental Review, 36, 179-199. https://doi.org/10.1016/j. dr.2015.04.001

Dennis, C.-L., Falah-Hassani, K., and Shiri, R. (2017). Prevalence of antenatal and postnatal anxiety: Systematic review and meta-analysis. British Journal of Psychiatry, 210(5), 315-323. https://doi.org/10.1192/bjp.bp.116.187179

Dombi, E., Berta, R., és Jámbori, S. (2019). Az ante- és posztnatális időszakban előforduló hangulati zavarokat befolyásoló szociális, szociodemográfiai és intrapszichés tényezők vizsgálata. Magyar Nőorvosok Lapja, 82, 257-266.

Dudas, R. B., Csatordai, S., Devosa, I., Töreki, A., Andó, B., Barabás, K., ... Kozinszky, Z. (2012). Obstetric and psychosocial risk factors for depressive symptoms during pregnancy. Psychiatry Research, 200(2-3), 323-328. https://doi.org/10.1016/j. psychres.2012.04.017

Dunkel Schetter, C., and Tanner, L. (2012). Anxiety, depression and stress in pregnancy: Implications for mothers, children, research, and practice. Current Opinion in Psychiatry, 25(2), 141-148. https://doi.org/10.1097/YCO.0b013e3283503680

EMMI (2017). Az Emberi Erőforrások Minisztériuma szakmai irányelve a pre-, peri- és posztnatális mentális zavarok baba-mama-papa egységében történő kezeléséről, Egészségügyi Közlöny, 66(4), 1120-1167.

Falah-Hassani, K., Shiri, R., and Dennis, C.-L. (2017). The prevalence of antenatal and postnatal co-morbid anxiety and depression: A meta-analysis. Psychological Medicine, 47(12), 2041-2053. https://doi.org/10.1017/S0033291717000617 
Grigoriadis, S., VonderPorten, E. H., Mamisashvili, L., Tomlinson, G., Dennis, C.-L., Koren, G., ... Ross, L. E. (2013). The impact of maternal depression during pregnancy on perinatal outcomes: A systematic review and meta-analysis. The Journal of Clinical Psychiatry, 74(4), e321-e341. https://doi.org/10.4088/JCP.12r07968

Hollins, K. (2007). Consequences of antenatal mental health problems for child health and development. Current Opinion in Obstetrics and Gynecology, 19(6), 568-572. https://doi.org/10.1097/GCO.0b013e3282f1bf28

Hompoth, E. A., Gálosi, N., Becsei, L., és Töreki, A. (2020). Depressziószűrés a várandósgondozásban. Eredmények Békéscsaba körzetéből. Orvosi Hetilap, 161(10), 374-381. https://doi.org/10.1556/650.2020.31659

Hompoth E. A., Töreki A., Baloghné Fürész V., és Németh G. (2017). A hangulati állapot alakulásának kockázati tényezői a perinatalis időszakban. Orvosi Hetilap, 158(4), 139-146. https://doi.org/10.1556/650.2017.30598

Kapitány, B. (2018). Az alapsokaság meghatározásának, a minta kialakitásának gyakorlati lépései. In Zs. Veroszta (Ed.), Kohorsz'18 Magyar Születési Kohorszvizsgálat módszertani leírás. A várandós kutatási szakasz előkészitése (pp. 11-18). Budapest: KSH Népességtudományi Kutatóintézet.

Kapitány, B., és Spéder, Zs. (2018). Gyermekvállalás. In Monostori J., Őri P., és Spéder Zs. (Eds.), Demográfiai portré (pp. 47-64). Budapest: KSH Népességtudományi Kutatóintézet.

Kingston, D., McDonald, S., Austin, M.-P., and Tough, S. (2015). Association between prenatal and postnatal psychological distress and toddler cognitive development: A systematic review. PLOS ONE, 10(5).

Kroenke, K., Spitzer, R. L., Williams, J. B. W., Monahan, P. O., and Löwe, B. (2007). Anxiety disorders in primary care: Prevalence, impairment, comorbidity, and detection. Annals of Internal Medicine, 146(5), 317-325. https://doi.org/10.7326/0003-4819-146-5200703060-00004

Lancaster, C. A., Gold, K. J., Flynn, H. A., Yoo, H., Marcus, S. M., and Davis, M. M. (2010). Risk factors for depressive symptoms during pregnancy: A systematic review. American Journal of Obstetrics and Gynecology, 202(1), 5-14. https://doi.org/10.1016/j. ajog.2009.09.007

Lefkovics, E., Rigó, J., Szita, B., Talabér, J., Kecskeméti, A., Kovács, I., and Baji, I. (2018). Relevance of anxiety in the perinatal period: Prospective study in a Hungarian sample. Journal of Psychosomatic Obstetrics \& Gynecology, 39(3), 220-227. https://doi.org/1 0.1080/0167482X.2017.1338264

Madigan, S., Oatley, H., Racine, N., Fearon, R. M. P., Schumacher, L., Akbari, E., ... Tarabulsy, G. M. (2018). A Meta-Analysis of Maternal Prenatal Depression and Anxiety on Child Socioemotional Development. Journal of the American Academy of Child \& Adolescent Psychiatry, 57(9), 645-657.e8. https://doi.org/10.1016/j.jaac.2018.06.012

NICE (2014). Antenatal and Postnatal Mental Health: Clinical Management and Service Guidance: Updated edition. Retrieved from http://www.ncbi.nlm.nih.gov/books/ NBK305023/

Nylen, K. J., Williamson, J. A., O’Hara, M. W., Watson, D., and Engeldinger, J. (2013). Validity of somatic symptoms as indicators of depression in pregnancy. Archives of Women's Mental Health, 16(3), 203-210. https://doi.org/10.1007/s00737-013-0334-2 
Radloff, L. S. (1977). The CES-D Scale: A Self-Report Depression Scale for Research in the General Population. Applied Psychological Measurement, 1(3), 385-401. https://doi.org/10.1177/014662167700100306

Rush, A. J., Zimmerman, M., Wisniewski, S. R., Fava, M., Hollon, S. D., Warden, D., ... Trivedi, M. H. (2005). Comorbid psychiatric disorders in depressed outpatients: Demographic and clinical features. Journal of Affective Disorders, 87(1), 43-55. https://doi.org/10.1016/j.jad.2005.03.005

Szabó, L., Boros, J., Fábián, I., Gresits, G., Hortobágyi, A., Kapitány, B., ... Spéder, Zs. (2020). Várandós kutatási szakasz. Technikai riport. Kohorsz'18 Magyar Születési Kohorszvizsgálat. Budapest: KSH Népességtudományi Kutatóintézet.

Szabó, L. (Ed.). (2020). Kohorsz'18 Magyar Születési Kohorszvizsgálat: Várandós kutatási szakasz, Technikai riport. Budapest: KSH Népességtudományi Kutatóintézet.

Szeifert, L. (2010). Depresszió és életminőség krónikus veseelégtelenségben szenvedő betegek körében. Budapest: doktori disszertáció.

Togher, K. L., Treacy, E., O’Keeffe, G. W., and Kenny, L. C. (2017). Maternal distress in late pregnancy alters obstetric outcomes and the expression of genes important for placental glucocorticoid signalling. Psychiatry Research, 255, 17-26. https://doi.org/10.1016/j.psychres.2017.05.013

Tuovinen, S., Lahti-Pulkkinen, M., Girchenko, P., Lipsanen, J., Lahti, J., Heinonen, K., ... Räikkönen, K. (2018). Maternal depressive symptoms during and after pregnancy and child developmental milestones. Depression and Anxiety, 35(8), 732-741. https://doi.org/10.1002/da.22756

Underwood, L., Waldie, K. E., D’Souza, S., Peterson, E. R., and Morton, S. M. B. (2017). A Longitudinal Study of Pre-pregnancy and Pregnancy Risk Factors Associated with Antenatal and Postnatal Symptoms of Depression: Evidence from Growing Up in New Zealand. Maternal and Child Health Journal, 21(4), 915-931. https://doi.org/10.1007/ s10995-016-2191-x

Veroszta, Zs. (Ed.). (2018). Kohorsz '18 Magyar Születési Kohorszvizsgálat módszertani leírás. A várandós kutatási szakasz előkészitése. Budapest: KSH Népességtudományi Kutatóintézet.

Waldie, K. E., Peterson, E. R., D’Souza, S., Underwood, L., Pryor, J. E., Carr, P. A., ... Morton, S. M. B. (2015). Depression symptoms during pregnancy: Evidence from Growing Up in New Zealand. Journal of Affective Disorders, 186, 66-73. https://doi.org/10.1016/j. jad.2015.06.009

Woody, C. A., Ferrari, A. J., Siskind, D. J., Whiteford, H. A., and Harris, M. G. (2017). A systematic review and meta-regression of the prevalence and incidence of perinatal depression. Journal of Affective Disorders, 219, 86-92. https://doi.org/10.1016/j. jad.2017.05.003

Zuckerman, B., Amaro, H., Bauchner, H., and Cabral, H. (1989). Depressive symptoms during pregnancy: Relationship to poor health behaviors. American Journal of Obstetrics \& Gynecology, 160(5), 1107-1111. https://doi.org/10.1016/0002-9378(89)90170-1

World Health Organization (2017). Depression and Other Common Mental Disorders:

Global Health Estimates. Geneva: World Health Organization. 


\section{SOCIO-DEMOGRAPHIC RISK FACTORS FOR PRENATAL DEPRESSION AND ANXIETY}

\section{ABSTRACT}

Depression and anxiety during pregnancy affect about one-fifth of pregnant women and has a negative impact on the health of both mother and child. According to previous research, their occurrence may be influenced by the socio-demographic characteristics of the mother. The aim of the present analysis is to explore the associations between prenatal depression and anxiety with socio-demographic risk factors among a representative Hungarian sample. The subject of the analysis was the data of the first wave of the Cohort '18 Growing Up in Hungary study $(n=7701)$. Anxiety and depressive symptoms were assessed using self-administered screening tools, which suggested that $12.5 \%$ of women were likely to have depression and $15.8 \%$ to have an anxiety disorder in the third-trimester of pregnancy. The likelihood of depression and anxiety during pregnancy was significantly correlated with each of the predictor variables (level of education, age, parity, partnership status, pregnancy planning, household income, own and partner employment, residence) in univariate statistical analyses. In the multivariate statistical analysis, the effects of the predictor variables remained significant, with the exception of the mother's and her partner's employment status, and explained $9-14 \%$ of the variance in prenatal depression and anxiety altogether. The results of the analysis confirmed that lower education, younger age, expecting the second or subsequent child, unmarried marital status, unplanned pregnancy, low household income and residence in Northern Hungary, the Northern Great Plain and Pest region are associated with a higher risk of depression and anxiety during pregnancy, though they account for only a small proportion of the differences between individuals. Among the risk factors examined, the most likely contributors to the likelihood of depressive and / or anxiety symptoms in the multivariate model were if the pregnant woman did not live with a partner, if she was expecting her third or subsequent child, if her household income was in the lower fifth, and if she lived in Pest region.

Keywords: prenatal depression; prenatal anxiety; pregnancy, risk factors 